Heaney, R. (2008). Australian equity mutual fund size effects. Accounting and Finance, $48(5), 807-827$.

(c) 2008 The Authors. Journal compilation (C) 2008 AFAANZ

This is the peer reviewed version of the following article: Heaney, R. (2008). Australian equity mutual fund size effects. Accounting and Finance, 48(5), 807-827, which has been published in final form at http://dx.doi.org/10.1111/j.1467-629X.2008.00267.x. This article may be used for non-commercial purposes in accordance with Wiley Terms and Conditions for self-archiving.

This version was made available in the UWA Research Repository on 12 November 2014 in compliance with the publisher's policies on archiving in institutional repositories.

Use of the article is subject to copyright law. 


\section{Australian Equity Mutual Fund Size Effects}

Richard Heaney*

RMIT University

JEL Code: F21, G11, G23

Key words: mutual funds, cash flows, performance

* Richard Heaney, School of Economics, Finance and Marketing, Business, RMIT University, level 12, 239 Bourke Street, Melbourne, 3000, Phone: 039925 5905, Fax: 039925 5986, Richard.Heaney@rmit.edu.au.

** Acknowledgements: I acknowledge Morningstar for providing access to their data. Thanks are also due to the participants at the 2007 FINSIA banking and Finance conference in Melbourne, the $14^{\text {th }}$ Global Finance Conference held in Melbourne in 2007, a University of Western Australia Business School seminar and a Victorian Funds Management Corporation seminar for their valued comments and suggestions. Finally, I thank Warren McKeown for sharing his experience and knowledge of the financial advice industry and the mutual fund products that are so important to this industry. 


\title{
Australian Equity Mutual Fund Size Effects
}

\begin{abstract}
Berk and Green (2004) propose a model of a superannuation fund industry, with a limited population of superior fund managers and a competitive investor market. In this market, superior fund managers capture the value they generate, leaving investors with a normal return on their investment. Further, it is argued that previous period returns, age of the fund and management costs explain variation in net cash flow paid into a fund over time. The Berk and Green predictions find some support in empirical tests, reported in this paper, based on Australian Morningstar retail and wholesale equity fund data over the period, 1995 to 2005.
\end{abstract}




\section{Introduction}

Recent Australian research into the impact of size on mutual fund performance suggests that small actively managed funds do not generally out perform larger funds (Gallagher and Martin, 2005). Yet, it is often argued that small actively managed funds should be better able to capture active investment opportunities given their small, more focused management team, low administration costs and low price impact. One factor that could negate this effect is the asset based fee structure that is commonly found in the mutual fund industry. While a small fund may generate excess returns, this success will attract cash into the fund resulting in increased fund size. As the fund grows the active manager eventually faces the decision of whether to remain small and generate excess returns for its investors or grow and maximise management fees. If it is true that small funds can outperform large funds then the very fee structure that is common throughout the industry may work against the possibility that small funds remain small and profitable.

The data used in this study consist of asset and return observations taken for individual Morningstar retail equity funds, wholesale non-tax paying equity trusts (NTP) and wholesale pooled superannuation equity trusts (PST) over the period January 1995 to November 2005. While the data are reported for individual funds, this information is also aggregated to provide fund family level information for later analysis.

There is little evidence of a size effect in the data though, consistent with previous research, there is some evidence of return based age effects as well as evidence that past returns, fund age and, to some extent management expenses, explain growth in fund assets. These results generally support the Berk and Green (2004) proposals and they are robust to fund family effects, equity market conditions 
and past equity market volatility. The following section provides a review of the literature, with data description in Section 3. Results of analysis appear in Section 4 and conclusions follow in Section 5.

\section{Literature review}

While some proponents argue that small firms are better able to execute active trades (Beckers and Vaughan, 2001) there are benefits derived from increasing the size of a fund including lower transaction costs and economies of scale. Nevertheless, the costs associated with increased size can be considerable and these include increased market impact, greater visibility, additional management complexity and difficulty in maintaining stated investment policies. It has been argued that there could be a trade off between the costs and benefits of growth such that an optimal fund size may exist (Perold and Salomon, 1991). Further, recent theory notes the lack of strong support for superior small fund performance and for persistence in returns. Given a competitive investment market and the compensation contracts widely adopted in the market, it has been argued that fund managers are rewarded though greater funds flow rather than superior investment returns (Berk and Green, 2004). Certainly, Sawicki and Finn (2002) provide Australian evidence of a smart money effect, with funds flowing to superior performing small funds.

While there is little research supporting the existence of an optimal fund size, traditional economic argument predicts that an equilibrium fund size will exist in a competitive market where price reflects value. Indeed, Perold and Salomon (1991) propose that there is an optimal fund size where marginal cost of additional growth equals the marginal benefit of no additional growth. Indro et al. (1999) test this proposal using a non-linear model to capture the relation between fund size and 
performance. They find some support for the Perold and Salomon (1991) proposition with an optimal fund size for their sample of approximately USD 1.0 billion. While there is little evidence of replication of this analysis in the USA or elsewhere, data availability makes replication of the study in Australia difficult at best. Further, the US analysis is based on a fairly limited sample of 683 actively managed USA funds over the years 1993 to 1995 inclusive. Finally, given the reliance of this model on price rather than funds flow it is unlikely that an optimal fund size will apply to the Australian funds included in this study.

There is some evidence of size effects in performance with smaller funds performing better than larger funds, particularly in comparisons between extremely small and the very large funds (in the USA, Chen et al., 2004; Droms and Walker, 1995; Ciccotello and Grant, 2001; in Australia, Chan et al., 2005; Bilson, Frino and Heaney, 2004; Holmes and Faff, 2000; Sawicki and Finn, 2002). ${ }^{1}$ Yet, Gallagher and Martin (2005) find no evidence to support the existence of a size effect in Australian funds over the period from 1991 to 2000 and this result finds support in the USA literature, particularly with Grinblatt and Titman (1989) who find no evidence of a size effect over the period from 1974 to $1984 .^{2}$ Chen et al. (2004) revisit this argument with a considerably larger sample spanning the period from 1962 to 1999. They argue that the size effects in their sample are liquidity driven, with the superior performing small funds investing in small illiquid stocks such that the observed excess returns compensate for increased liquidity costs.

While the focus of this paper is on individual fund performance, Chan et al. (2005) and Chen et al. (2004) also analyse the impact of fund family size where fund

\footnotetext{
${ }^{1}$ This is only observed in the aggressive growth category where small funds out perform large funds.

${ }^{2}$ While smaller funds are seen to earn higher returns before transaction costs they also incurred greater levels of transaction costs resulting in no statistically significant difference across the size-based quartiles after transaction costs.
} 
families consist of a number of funds controlled by one institution. While there can be considerable variation in size and stated investment objective of individual funds within a family, these groups have been treated as a single entity in recent research. ${ }^{3}$ Chan et al. (2005) use daily trades from a sample of larger Australian fund families and they find that purchasing pressure generated by cash inflows is more severe for larger fund families, resulting in small fund families outperforming larger fund families. Thus, while there is some evidence of a size effect in individual funds, particularly for very small funds, Chan et al. (2005) argue that a size effect may also exist at the fund family level. Chen et al. (2004) find similar results for US mutual funds. ${ }^{4}$

Berk and Green (2004) question the existence of an optimal fund size or even the existence of a size effect in equilibrium. They construct a model that exhibits many of the key features of the mutual funds industry including differential manager ability, decreasing returns to scale, the process of learning about manager performance through past returns, the existence of open-ended funds, the wide spread use of management fees expressed as a percentage of funds under management and the existence of a competitive investment market with a large number of investors seeking the best possible return on their investment. Both managers and investors are assumed to learn about the success of management policy through past returns. A key result of the model is that with open-ended funds the unit price cannot reflect the success of a manager's active investment because superior performance is reflected through funds flow. Essentially, relatively scarce superior managers capture the rents that they create though increased management fees generated by the inflow of assets

\footnotetext{
${ }^{3}$ Gervais, Lynch and Musto (2005) explore the monitoring problems that fund families face and predict that monitoring efficiency is positively related with family size.

${ }^{4}$ Results for individual fund portfolio returns, as well as fund family portfolio returns, are reported in the first part of the analysis section of this paper. Dummy variables are also included in multivariate analysis to deal with fund family impacts on individual fund net cash flows.
} 
in response to superior past returns. Yet, while the level of management fees increases as the fund grows larger, the ability of managers to create superior returns decreases. In this model there is no market wide equilibrium fund size. Each fund has its own optimal size and this is determined by the skill of the manager and the fund's cost function.

The Berk and Green (2004) model predicts that there will be no size effect in equilibrium yet the literature is mixed with respect to the existence of a small fund effect. Another prediction of the model is that older funds will not perform as strongly as younger funds, yet Sawicki and Finn (2002) argue that the age effect evident in their Australian data is explained by size. Thus, it is important to revisit the question of size and age effects using a larger and more recent data set. Further, it is important to test some of the other Berk and Green (2004) predictions including the existence of a positive relation between asset growth and past returns, and a negative relation between asset growth and both fund age and management fees.

\section{Data}

Monthly fund return, net of fees and taxes, is supplied by Morningstar for all of the funds that fall within the wholesale fund classifications of NTP and PST and for the Australian retail equity fund classification over the period January 1995 to September 2005. ${ }^{5}$ The NTP fund returns are after expenses but before tax and the PST and the Retail equity trusts are after expenses and taxes. The PST trusts are superannuation funds and so face a $15 \%$ income tax rate while the retail equity trusts are also subject to Australian income tax legislation. Wholesale NTP and PST funds are selected for analysis because of the level of monitoring that is undertaken by

\footnotetext{
${ }^{5}$ The word "fund" is used here to refer to a Morningstar product.
} 
investors in the wholesale market while the retail equity funds are included because of the importance of this sector of the market for individual investors and because of the similarities that exist between this group and the equity funds generally analysed in the USA. There are 420 funds that fall within the NTP classification, 130 under the PST classification and 655 under the Retail equity classification over the study period, though there are no more that 290 NTP funds, 91 PST funds and 391 Retail equity funds respectively with a full set of data in any one of the years spanned by the study (Table 1). This is to be expected over a 10-year period given the incidence of missing observations and the fact that the sample includes new funds, failed funds and surviving funds. These funds are also categorised by fund family, with 106 fund families in the Retail equity classification, 78 in the NTP classification and 29 in the PST classification.

[Insert Table 1 about here]

The individual fund returns ( $R_{i, t}$ for fund $i$ from time $t-1$ to time $t$ ), and assets under management weighted fund family returns, are measured in terms of continuously compounding rates of return per month, as is the growth rate in assets under management ( $R_{A U M, i, t}$ for fund $i$ from time $t-1$ to time $t$ ). These are defined as follows:

$$
\begin{aligned}
& R_{i t}=\ln \left(P_{i t} / P_{i t-1}\right) \\
& R_{(A U M) i t}=\ln \left(A U M_{i t} / A U M_{i t-1}\right)
\end{aligned}
$$

Where $P_{i t}$ is the Morningstar return index value for fund $i$ at time $t, A U M_{i t}$ is assets under management for fund $i$ at time $t$. The sample size varies considerably over time with a rapid increase in the number of funds (products) listed in the Morningstar data set from 1999 (Table 1). Further, while there are no gaps in return index values there are gaps in the asset under management values. Linear 
interpolation is used to fill these gaps wherever possible. The average size of a fund in the study is AUD 174.57 million for the NTP funds, AUD 65.81 for the PST funds and AUD 79.34 for the retail equity funds. There is considerable variation in the size of the individual funds as is apparent from the variation in average size from the smallest to the largest size based portfolios reported in Table 1. Similar variation is also evident for fund families and so separate results are not reported here. Only the most recent management fee information is available for this study and so management fee data are used as a proxy, relying upon the argument that management fees do not tend to change much over time (Berk and Green, 2004).

Data are also required for the calculation of risk-adjusted returns (alpha) using a four-factor model (Elton, Gruber and Blake, 1996; Gruber, 1996) and excess returns. ${ }^{6}$ The Australian All Ordinaries Share Market Accumulation Index is used as a proxy for the market return and this is used in the calculation of both the risk adjusted returns and excess returns. The Australian Small Ordinaries Share Market Accumulation Index is used to approximate returns on small cap stocks and the S\&P ASX 100 Accumulation Index is used to estimate the return on large cap stocks. The Australian book to market factor is obtained from the Kenneth French's web site. ${ }^{7}$ The 90-day bank accepted bill rate and the 10-year Government bond indicator rate are used in the calculation of the monthly risk free rate and the monthly rate of return on a bond portfolio respectively. ${ }^{8}$

\footnotetext{
${ }^{6}$ Choice of asset pricing model does not seem to have much impact on the analysis with use of the Jensen measure or the alpha from a Fama and French three factor model having little impact on the results.

${ }^{7}$ The data provided on this web site is quite extensive and includes book to market factors for both the US and a range of other countries including Australia. The Australian data is used in this analysis. (http://mba.tuck.dartmouth.edu/pages/faculty/ken.french/data_library.html)

${ }^{8}$ The yield curve is assumed flat in the neighbourhood of the 90 to 120 day period for bank accepted bills and in the neighbourhood of 10 years and 10 years plus one month for the bonds. In both cases the one month rate of return is calculated under the assumption that the security is purchased at the beginning of the month and sold at the end of the month at the yields prevailing at that time.
} 
Control variables are also collected for multivariate analysis of net cash inflows. These include a set of fund family dummy variables, excess fund return volatility and a dummy variable to capture equity market conditions. The fund family dummy variables are included in analysis to control for the possibility of a common fund manager affecting all funds within a particular fund family as identified in Chan et al. (2005) and Chen et al. (2004). There are 106 fund family dummy variables for the retail equity funds, 78 for the NTP funds and 29 for the PST funds with a fund family dummy variable taking a value of one where the fund is associated with a particular fund family and a value of zero otherwise. While the total number of fund families is quite large the actual number included in analysis varies considerably from year to year with a general tendency for the number of fund families to increase over the 10-year period of the study, particularly in the last couple of years of the study, in line with recent increases in the range of financial institution investment offerings. It is possible that higher order moments in mutual fund excess returns, such as excess return volatility, have an impact on cash flows into the fund. ${ }^{9}$ For example, risk averse investors prefer to invest with funds that exhibit less volatile returns, all else held constant. The standard deviation in excess fund return over a 12-month period is used as an estimate for volatility in this analysis. Market wide conditions could also have an impact on net cash flows into the funds. During periods of high share market returns investors may be more willing to invest in equity-based mutual funds and so an equity market conditions dummy variable is calculated, taking a value of one when the share market return for the year exceeds the average share market return over the period from 1995 to 2005 and zero otherwise.

\footnotetext{
${ }^{9}$ While volatility is included in this analysis, higher order moments such as skewness and kurtosis might also be included. Analysis of these higher order moments is left to future research.
} 


\section{Analysis}

This section focuses on fund performance and fund cash flows with an emphasis on testing some of the Berk and Green (2004) predictions. In the first sub section, analysis deals with the impact of size and age on performance. While the Berk and Green model predicts that there will not be a size effect in returns the model does suggest that younger funds may be observed to outperform older funds. Survivorship bias free portfolios are used in testing for size and age effects in fund returns. Tests of the Berk and Green (2004) predictions of a positive relation between asset growth and past returns and a negative relation between asset growth and both fund age and management fees are described in the second sub section. ${ }^{10}$

\subsection{Size and age effects}

Given the importance of survivorship effects in analysis of individual fund performance, all available funds are allocated into five groups by size and into two groups by age at the beginning of each month. ${ }^{11}$ Thus, ten size/age individual fund portfolios are created and portfolio returns are calculated for each month, beginning with size and age information available at the end of December 1994, which is used in the creation of the January 1995 portfolios. ${ }^{12}$ The process generates a set of ten separate time series for the full study period, from January 1995 to September 2005, one for each size/age based portfolio. Given the importance of fund families, portfolios are also created by fund family though, due to the small number of fund

\footnotetext{
${ }^{10}$ Due to data limitations, the management fee effect tests are restricted to the use of September 2005 management fees as reported in available Morningstar data. There is some evidence to suggest that the management expense ratios do not vary much over time (Berk and Green, 2004).

${ }^{11}$ Fund family age is asset under management weighted age of the funds that make up the family. ${ }^{12}$ Portfolios were chosen to allow analysis of size and age but to also ensure that there were sufficient observations in each portfolio in each month of the study period to provide portfolio average return estimates.
} 
families available for analysis, only three size based portfolios are used along with two age based portfolios in this case.

A comparison of the size/age portfolio returns is reported in Table 2. The average total return for each of the size/age portfolios is reported for the full period, 1995 to 2005 , and for the sub periods, 1995 to 1999 and 2000 to 2005 . Retail equity portfolio results are reported in Panel A while Panel B includes results for the wholesale NTP funds and Panel C for the wholesale PST funds. There is no evidence of small funds (S5) earning statistically significant superior returns to large funds (S1). Indeed, for the retail equity funds and the wholesale PST funds, the smallest funds generally perform worse than largest funds over the total period as well as in the sub-periods, 1995 to 1999 and 2000 to 2005 . There is no significant size effect evident for the wholesale NTP funds. There were no statistically significant small fund family size effects and so these results are not reported separately.

[Insert Table 2 about here]

Portfolios are also split equally between two age portfolios, one for younger funds $(\mathrm{Y})$ and the other for older funds $(\mathrm{O})$. In general the younger funds earn greater returns than the older funds though this difference is not generally statistically significant. The only exception is for smallest retail equity funds where young small funds earn returns that are statistically significantly greater than returns reported for the old small funds group. The sub period analysis of the retail equity funds show that this effect seems to be most evident in the 1995 to 1999 period. There is no statistically significant effect evident in the post 1999 sub period. ${ }^{13}$

Analysis is also conducted for fund families to test for the possibility of smaller fund families earning greater raw returns than larger fund families or younger

\footnotetext{
${ }^{13}$ As with the raw return based size comparisons there was no statistically significant difference observed for fund family age based portfolio comparisons.
} 
fund families earning greater raw returns than older fund families. There is no evidence of statistically significant differences across size or age for the fund family portfolios and so these results are not reported separately here.

Comparisons based solely on returns are immediately subject to question because there is no accounting for variation in risk. As a result the comparisons are repeated using risk adjusted returns based on the four-factor model proposed by Elton, Gruber and Blake (1996) and Gruber (1996). ${ }^{14}$ In this model the excess return on fund $i$, or fund family $i$, at time $t\left(R_{i t}-R_{f t}\right)$ is expressed as a function of the market risk premium at time $t,\left(R_{m t}-R_{f t}\right)$, the size or SML premium, $\left(R_{s t}-R_{l t}\right)$, book to market or HML premium, $\left(R_{g t}-R_{v t}\right)$ and a bond premium, $\left(R_{b t}-R_{f t}\right)$. This fourfactor model is defined as follows:

$R_{i t}-R_{f t}=\alpha_{i}+\beta_{m}\left(R_{m t}-R_{f t}\right)+\beta_{s}\left(R_{s t}-R_{l t}\right)+\beta_{g}\left(R_{g t}-R_{v t}\right)+\beta_{b}\left(R_{b t}-R_{f t}\right)+\varepsilon_{i t}$

$\alpha_{i} \quad=$ risk adjusted return (alpha) for fund $i$, or fund family $i$

$R_{f t} \quad=$ risk-free return for the month ending time $t$

$R_{m t} \quad=$ return on the market at time $t$

$R_{s t} \quad=$ return on the small stock portfolio at time $t$

$R_{l t} \quad=$ return on the large stock portfolio at time $t$

$R_{g t} \quad=$ return on the growth stocks at time $t$

$R_{v t} \quad=$ return on the value stocks at time $t$

$R_{b t} \quad=$ return on the bond portfolio at time $t$

$\varepsilon_{i t} \quad=$ random error term for fund $i$ in period $\mathrm{t}$

The Risk adjusted return estimates provide a much richer story and these are reported in Table 3 for each of the individual fund based size/age portfolios. ${ }^{15}$ There is a separate panel for each of the three fund categories, Panel A for retail funds, Panel

\footnotetext{
${ }^{14}$ The results do not differ much with the choice of either one factor, three factor or the four factor models though the four factor model results are reported here because this model specifically caters for the possibility that funds could hold substantial levels of cash and bonds as well as equities from time to time.

${ }^{15}$ While similar analyses were undertaken for the fund families these are not reported separately in this paper as they tell a similar story.
} 
for NTP wholesale funds and Panel C for PST wholesale funds. The four-factor assetpricing model is fitted to the ten size/age portfolios using seemingly unrelated regression (SURE). This approach allows statistical tests to be conducted across the various size/age portfolio risk adjusted return coefficients (alphas) with the probabilities from the age tests reported in the row labelled "Prob." of each of the panels in Table 3. Similarly, the probabilities from tests for difference in excess return between the smallest and the largest quintile are reported in the column labelled "Prob.". Differences in the coefficients are also reported to facilitate comparisons. The t-test probabilities for each of the risk adjusted return coefficients (alphas) are reported in parentheses below the estimated parameters.

[Insert Table 3 about here]

There is little evidence of small funds statistically significantly out performing large funds in Table 3. This is consistent with the full period results reported for the raw returns in Table 2. In all cases the largest retail fund portfolio risk adjusted returns exceed the smallest retail fund portfolio risk adjusted returns regardless of the period chosen. This applies to both individual fund analysis appearing in Table 3 and the fund family analysis (not reported separately). The PST fund comparisons also provide little evidence of small funds or small fund families earning consistently superior returns. While there is some evidence of a size effect for the old fund group over the period 1995 to 1999 this is not evident in the following sub period. It is interesting to note that there is a size effect evident in the NTP individual fund risk adjusted returns and this is particularly evident for the younger funds and younger fund families.

There is considerably more evidence of younger funds out performing older funds in this analysis, after adjustment for risk. This is particularly so for retail fund 
and the PST fund categories. While not reported separately this result is not so evident for the fund families. A key result from Panel A, Table 3, is that small old retail equity funds performed significantly worse than small young retail equity funds and this is consistent with the analysis reported in Table 2. There is also evidence of statistically significant age effects in the sub period analysis for the retail funds, with size group 2 and size group 4 in the 1995 to 1999 analysis and size group 1 in the 2000 to 2005 analysis showing evidence of younger fund out performing old funds. Greater consistency is apparent for the age effect tests in the NTP analysis (Panel 2 of Table 3) with a statistically significant age effect for size group 2 and size group 4 regardless of the period chosen for analysis. Age effects are also evident in some of the size groups for the PST funds with a statistically significant age effect for size group 3 for the full period analysis and for the 1995 to 1999 analysis while there are statistically significant age effects for the size groups 2, 4 and 5 in the 2000 to 2005 analysis.

While there is not much evidence of superior small fund performance the statistically significantly inferior performance observed for the small old fund category for the retail funds is worthy of note. The literature has often argued that small funds tend to outperform larger funds yet this is not the case in this analysis, consistent with Gallagher and Martin (2005). It is also important to note the existence of an age effect in the data, particularly evident in the risk-adjusted returns (Table 3). ${ }^{16}$ Younger funds tend to earn greater raw returns than older firms though this is rarely statistically significant (Table 2). Further, young fund risk adjusted returns (Table 3) tend to exceed older fund risk adjusted returns and this difference is statistically significant in a number of cases. Further, these differences are not solely

\footnotetext{
${ }^{16}$ This is also observed to a lesser extent in the fund family results, not reported separately here.
} 
located in the smallest fund categories. Indeed, statistically significant age based variation is spread across the various size based classifications. Thus, while it is not possible to reject the null of no difference in performance between large and small funds there is some evidence, particularly after adjustment for risk, to support the argument that younger funds out perform older funds. These results support the Berk and Green (2004) predictions of no size effect with the possibility of age effects in fund returns, consistent with the superior managers driving younger fund performance and attracting further cash flows into their fund.

\subsection{Funds Flow and Performance}

While there is some variation in the relative performance of size quintile based portfolios there is little evidence to support the existence of superior small fund performance on average, consistent with the arguments of Berk and Green (2004). Nevertheless, there is some evidence of younger funds earning greater risk adjusted returns than older funds consistent with the proposition that superior returns are earned up until the fund grows too large to continue this performance (Berk and Green, 2004). In this section the Berk and Green (2004) fund cash flow predictions are tested and one of the key relations observed in the Berk and Green (2004) model is the relation that exists between asset growth, excess returns, age of the fund and management fees. ${ }^{17}$ This is defined as:

$$
\frac{q_{t}-q_{t-1}}{q_{t-1}}=\frac{r_{t}}{f}\left(\frac{\omega}{\gamma+\tau \omega}\right)+\frac{r_{t}^{2}}{4 f^{2}}\left(\frac{\omega}{\gamma+\tau \omega}\right)^{2}
$$

\footnotetext{
${ }^{17}$ Sawicki and Finn (2002) also explore some of these issues though their paper is focused on identifying the incidence of smart money flowing to strongly performing funds. The object of this analysis is to test the propositions put forward by Berk and Green in an Australian context.
} 
Where $q_{t}$ is the assets under management at time $t, r_{t}$ is return in excess of a benchmark return earned by the portfolio from time $t$ to time at time $t-1, f$ is the management fees and the parameters, $\tau$ is the age of the fund, $\omega$ and $\gamma$, refer to the precision of inferring manager skill estimates from observed returns and the precision of prior beliefs about manager skill respectively. The relationship in equation (3) assumes that investors observe the return for the period, $r_{t}$ and then make a decision as to whether or not they will invest with the firm at the end of the period.

If it is assumed that the precision of estimates about manager skill from observed returns and the precision of prior beliefs about manager skill are fixed then it is possible to draw testable predictions from Equation (3). For example, equation (3) suggests a positive relation exists between growth in assets under management and prior period return. Essentially, funds with superior performance in one period attract cash in future periods. There is also a negative relation between growth in assets under management and fund age. This is consistent with the argument that when the fund is first set up the successful manager is able to generate excess returns and attract cash flows but over time, as the fund grows in size, superior performance becomes less feasible. ${ }^{18}$ It is also evident from equation (3) that the growth in assets under management is decreasing in management fees. If there are two funds, identical in all but management fees, the fund with the higher management fees will exhibit weaker after fee performance and so it will attract less cash and tend not to grow as large.

Equation (3) is a non-linear model and so in order to simplify statistical tests a first order Taylor series expansion of equation (3) is used to give the following linear expression.

\footnotetext{
${ }^{18}$ This also ties in with the age effects observed in the previous sub section where the risk adjusted returns of younger funds generally exceed the risk adjusted returns of older funds.
} 


$$
R_{(A U M) i t}=\alpha_{0}+\alpha_{1} r_{i t-1}+\alpha_{2} \tau_{i t}+\alpha_{3} f_{i t}
$$

The Berk and Green (2004) definitions are followed in calculation of fund growth and fund excess returns, where $R_{(A U M) i t}$ is the growth in assets under management for fund $i$ at time $t, r_{i t}$ is the fund $i$ return in excess of the Australian All Ordinaries share price index at time $t,\left(R_{i t}-R_{m t}\right), \tau_{i t}$ is the age of fund $i$ at time $t$, $f_{i t}$ is an estimate of the management fees of fund $i$ at time $t$ and the $\alpha_{i}$ are the estimated coefficients. The Australian All Ordinaries index is selected as a benchmark because of its widespread use in the literature as well as by market participants for benchmarking purposes.

While equations (3) and (4) include the impact of management fees, this is not available over the study period for each of the funds for each year. It has been argued that the management expense ratio is fairly constant over time (Berk and Green, 2004) and so equation (4) is estimated using the management expense ratio reported by Morningstar as at the end of 2005. Further, the model is expanded to include control variables to capture the impact of fund family dummy variables $\left(F M D_{j}\right)$ for funds $j=1$ to $J$, lag fund excess return volatility for fund $i$ at time $t-1\left(\sigma_{i t-1}\right)$ and an equity market condition dummy variable $\left(E M C D_{t}\right)$. The residual term $\left(\varepsilon_{i t}\right)$ is the final element in the model giving equation (5).

$$
R_{(A U M) i t}=\alpha_{0}+\alpha_{1} r_{i t-1}+\alpha_{2} \tau_{i t}+\alpha_{3} f_{i t}+\sum_{j=1}^{J} \alpha_{4 j} F M D_{j}+\alpha_{5} \sigma_{i t-1}+\alpha_{6} E M C D_{t}+\varepsilon_{i t}
$$

Random effects panel data analysis is used in estimation of equation (5) as reported in Table $4 .^{19}$ There is some consistency across the three fund classifications with respect to the coefficient sign and statistical significance of the lag returns and

\footnotetext{
${ }^{19}$ There are a number of very large growth and excess return numbers in the data set and so a check on the analysis is provided using pooled robust regression. The results are broadly similar to those produced by random effects panel analysis.
} 
fund age. The lag excess return coefficient is generally positive and statistically significant for the full period and for the 2000 to 2005 sub period though there is some variation in the 1995 to 1999 sub period, particularly for the PST funds. ${ }^{20}$ This result is also supportive of the Berk and Green (2004) prediction that high excess returns in one period lead to growth in assets under management in the following period. The estimated fund age coefficients have a negative sign and are statistically significant for the full period as well as for most of the sub period analyses reported in Panels A, B and C of Table 4. This is consistent with the Berk and Green prediction that old funds attract lower levels of asset growth than younger funds.

[Insert Table 4 about here]

While the management expense ratio coefficient is negative in all analyses as predicted by Berk and Green (2004), it is generally not statistically significant. The exception is the coefficient estimated for the full PST fund model over from 1995 to 2005. In this case, the coefficient is both statistically significant and negative. Thus, while there is little statistical support for the Berk and Green (2004) prediction that higher management fees result in lower assets under management there is some consistency in coefficient sign for each of the three fund categories that are included in the analysis.

A number of control variables are also included in equation (5). These include lagged excess fund return volatility, a dummy variable set up to capture equity market conditions and a full set of fund family dummy variables to capture the impact of fund family effects. There is considerable variation in the sign and the statistical significance of the coefficients estimated for these variables.

\footnotetext{
${ }^{20}$ The exception is the estimated PST fund coefficient for the 1995 to 1999 sub period when the management expense ratio is excluded from the model.
} 
The lag volatility coefficient is generally positive with the exception of the 1995 to 1999 period for both the retail funds and for the NTP funds. The estimated coefficients are statistically significant for all of the retail fund regressions yet there is only one of the wholesale fund based analyses, the PST regression excluding the management fees variable, where the coefficient is statistically significant. It is possible that wholesale equity funds behave differently from retail funds in terms of their sensitivity to excess return volatility though it is difficult to explain the variation in coefficient sign over the sub-periods. The incidence of positive coefficients is of particular interest because this suggests that funds with more volatile excess returns in one period attract greater levels of cash in the following period. ${ }^{21}$

The equity market conditions variable is not statistically significant for the PST fund analysis and is statistically significant in only one regression for the retail equity funds. While there are three statistically significant coefficients for the NTP fund analysis these are associated with negative estimated coefficients. It appears that, at least for the NTP category of funds, above average equity market conditions are associated with reduced assets under management. Again, the coefficient estimates for this control variable vary considerably across the fund categories and over time.

The estimated coefficients for the fund family dummy variables are not reported separately due to the large number of dummy variables that are included in the analysis though it should be noted that a number of these estimated coefficients are statistically significant. Thus, there is some evidence that financial organisations

\footnotetext{
${ }^{21}$ One possible explanation is that high volatility is associated with high returns resulting in a positive relation between with next period net cash inflows and both volatility and returns. Given that these variables are included as control variables and that there are no a priori predictions concerning their sign further analysis of this question is left to future research.
} 
responsible for a fund family have an impact on the asset growth of the individual funds within the family.

\section{Conclusion}

Berk and Green (2004) provide an explanation for why fund size effects are so rare in empirical studies, except perhaps where liquidity costs are substantial (Chen et $a l ., 2004)$. The very nature of the investment market may actually work against the possibility of superior performing small funds remaining small and thus it is unlikely that superior individual fund performance will be observed for extended periods of time. The results of this study are generally consistent with this proposition. There is some evidence to support the contention that younger funds outperform older funds and these results are evident both at the individual fund level and the fund family level. These results do not appear to be driven by survivorship bias as monthlyrebalanced size/age portfolios are used in the initial analysis of raw returns as well as risk-adjusted returns.

Berk and Green (2004) argue that the key mechanism that ensures small funds grow until they can no longer earn excess returns is the attraction of cash flows to strong past returns. Tests of this prediction generally support the existence of positive relation between fund growth and prior year excess returns. There is also evidence of a negative relation between asset growth and fund age. Essentially, it is argued that older funds, approaching their equilibrium size, report lower excess returns and attract less cash. Further, there is some evidence of management fee effects, supporting the argument that funds that charge higher fees attract lower levels of cash. These results are robust to the impact of fund family effects, fund excess return volatility and equity 
market conditions. Thus the Berk and Green (2004) model provides some insight into the behaviour of mutual funds in the Australia. 


\section{References}

Beckers, S., and G. Vaughan, 2001, Small is Beautiful, Journal of Portfolio Management 27, 9-17.

Berk, J.B., and R.C. Green, 2004, Mutual Fund Flows and Performance in Rational Markets, Journal of Political Economy 112, 1269-1295.

Bilson, C., A. Frino and R. Heaney, 2004, Australian Retail Superannuation Fund Performance, Accounting Research Journal 17, 43-56.

Gervais, S., A.W. Lynch, and D.K. Musto, 2005, Fund Families as Delegated Monitors of Money Managers, Review of Financial Studies 18, 1139-1169.

Chan, H., R.W. Faff, D.R. Gallagher, and A. Looi, 2005, Fund Size, Fund Flow, Transaction Costs and Performance: Size Matters! Available at SSRN: http://ssrn.com/abstract=697581.

Chen, J., H. Hong, M. Huang, and J.D. Kubik, 2004, Does Fund Size Erode Mutual Fund Performance? The Role of Liquidity and Organization, American Economic Review 94, 1276-1303.

Ciccotello, C.R. and C.T. Grant, 2001, Equity Fund Size and Growth: Implications for Performance and Selection, Financial Services Review 5, 1-12.

Droms, W.G., and D.A. Walker, 1995, Determinants of Variation in Mutual Fund Returns, Applied Financial Economics 5, 383-389.

Elton, E.J., M.J. Gruber, and C.R. Blake, 1996, The Persistence of Risk-Adjusted Mutual Fund Performance, Journal of Business 69, 133-157.

Fama, E.F., and K.R. French, 1992, The Cross-Section of Expected Stock Returns, Journal of Finance 47, 427-465.

Fama, E.F., and K.R. French, 1993, Common Risk Factors in the Returns on Stocks and Bonds, Journal of Financial Economics 33, 3-56.

Gallagher, D.R., and K.M. Martin, 2005, Size and Investment Performance: A Research Note, Abacus 41, 55-65.

Grinblatt, M., and S, Titman, 1989, Mutual Fund Performance: An Analysis of Quarterly Portfolio Holdings, Journal of Business 62, 393-416.

Gruber, M.J., 1996, Another puzzle: The Growth in Actively Managed Mutual Funds Journal of Finance 51, 783-810.

Holmes, K.A., and R.W. Faff, 2000, Cross-Sectional Determinants of Managed Fund Risk and Performance: Evidence for Australian Equity Trusts, Accounting, Accountability and Performance 6, 55-75. 
Indro, D.C., C.X. Jiang, M.Y. Hu, and W.Y. Lee, 1999, Mutual Fund Performance: Does Fund Size Matter?, Financial Analysts Journal 55, 74-87.

Perold, A.F., and R.S. Salomon, 1991, The Right Amount of Assets Under Management, Financial Analysts Journal May-June, 31-39.

Sawicki, J. and F. Finn, 2002, Smart Money and Small Funds, Journal of Business Finance and Accounting, 29, 825-846. 
Table 1

Average fund size (AUD millions)

\begin{tabular}{|c|c|c|c|c|c|c|c|}
\hline Period & $\begin{array}{l}\text { Size } 1 \\
\text { (Large) }\end{array}$ & Size 4 & Size 3 & Size 4 & $\begin{array}{l}\text { Size } 5 \\
\text { (Small) }\end{array}$ & $\begin{array}{l}\text { All } \\
\text { Funds }\end{array}$ & $\begin{array}{l}\text { No. of } \\
\text { Obs. }\end{array}$ \\
\hline \multicolumn{8}{|c|}{ Panel A: Retail Equity Funds } \\
\hline 1995 & 189.29 & 29.06 & 13.83 & 3.89 & 0.97 & 47.78 & 124 \\
\hline 1996 & 200.61 & 29.33 & 13.11 & 4.24 & 0.90 & 49.16 & 137 \\
\hline 1997 & 239.40 & 38.75 & 14.63 & 5.74 & 1.21 & 59.95 & 145 \\
\hline 1998 & 304.28 & 47.53 & 15.87 & 6.16 & 1.24 & 74.40 & 157 \\
\hline 1999 & 336.33 & 46.54 & 14.82 & 5.31 & 1.10 & 79.80 & 173 \\
\hline 2000 & 397.65 & 50.74 & 14.39 & 4.86 & 1.16 & 94.26 & 184 \\
\hline 2001 & 440.16 & 52.59 & 17.47 & 6.08 & 0.98 & 104.00 & 189 \\
\hline 2002 & 432.10 & 49.12 & 12.80 & 3.70 & 0.64 & 99.67 & 245 \\
\hline 2003 & 363.02 & 37.98 & 11.54 & 4.04 & 0.59 & 83.43 & 280 \\
\hline 2004 & 393.90 & 36.37 & 10.28 & 2.37 & 0.23 & 88.39 & 331 \\
\hline 2005 & 411.42 & 34.64 & 10.40 & 3.30 & 0.54 & 91.85 & 391 \\
\hline $1995-2005$ & 337.10 & 41.15 & 13.56 & 4.52 & 0.87 & 79.34 & 214 \\
\hline \multicolumn{8}{|c|}{ Panel B: NTP Wholesale Funds } \\
\hline 1995 & 723.02 & 18.27 & 6.70 & 1.94 & 0.07 & 153.84 & 39 \\
\hline 1996 & 879.02 & 26.80 & 10.94 & 4.67 & 0.27 & 180.57 & 46 \\
\hline 1997 & 828.16 & 37.42 & 16.54 & 6.07 & 0.79 & 172.76 & 62 \\
\hline 1998 & 676.36 & 51.88 & 21.31 & 6.88 & 0.73 & 148.45 & 82 \\
\hline 1999 & 579.74 & 56.78 & 20.07 & 4.38 & 0.65 & 131.40 & 121 \\
\hline 2000 & 708.86 & 84.67 & 27.58 & 6.88 & 1.02 & 166.99 & 139 \\
\hline 2001 & 624.24 & 105.52 & 28.09 & 6.70 & 0.90 & 151.13 & 163 \\
\hline 2002 & 795.57 & 111.59 & 24.11 & 5.85 & 0.85 & 187.59 & 205 \\
\hline 2003 & 837.21 & 103.32 & 24.04 & 5.80 & 0.89 & 193.05 & 232 \\
\hline 2004 & 848.58 & 180.47 & 47.48 & 13.88 & 2.62 & 217.60 & 242 \\
\hline 2005 & 847.79 & 173.58 & 46.96 & 13.77 & 2.39 & 216.90 & 290 \\
\hline $1995-2005$ & 758.96 & 86.39 & 24.89 & 6.98 & 1.02 & 174.57 & 147 \\
\hline \multicolumn{8}{|c|}{ Panel C: PST Wholesale Funds } \\
\hline 1995 & 143.30 & 9.13 & 2.67 & 0.38 & 0.00 & 31.10 & 20 \\
\hline 1996 & 144.68 & 12.83 & 4.00 & 0.45 & 0.00 & 33.74 & 24 \\
\hline 1997 & 236.36 & 41.49 & 13.56 & 4.86 & 0.74 & 54.26 & 23 \\
\hline 1998 & 235.30 & 44.63 & 11.29 & 3.31 & 0.17 & 58.94 & 30 \\
\hline 1999 & 277.19 & 55.78 & 9.69 & 2.98 & 0.48 & 69.22 & 35 \\
\hline 2000 & 356.18 & 55.98 & 14.76 & 3.16 & 0.44 & 88.30 & 39 \\
\hline 2001 & 295.74 & 44.35 & 17.81 & 2.98 & 0.31 & 72.24 & 45 \\
\hline 2002 & 362.85 & 67.83 & 21.64 & 4.92 & 0.74 & 91.60 & 45 \\
\hline 2003 & 292.40 & 60.24 & 15.22 & 5.13 & 0.86 & 72.76 & 42 \\
\hline 2004 & 208.55 & 35.47 & 7.44 & 0.98 & 0.01 & 49.25 & 52 \\
\hline 2005 & 500.54 & 13.65 & 2.94 & 0.77 & 0.12 & 102.50 & 91 \\
\hline $1995-2005$ & 277.55 & 40.13 & 11.00 & 2.72 & 0.35 & 65.81 & 41 \\
\hline
\end{tabular}

Data consists of 655 Retail Australian equity funds, 420 wholesale NTP Australian equity funds and 130 wholesale PST Australian equity funds from December 1994 to September 2005 (Morningstar). Only those funds with both assets under management and fund return are included in this analysis though the actual sample size will vary with the analysis that is conducted. The funds are allocated equally into five portfolios by total assets under management with the smallest fund portfolio allocated the code Size 5 and the largest allocated the number Size 1. No. of Obs. refers to the number of funds that are included in this analysis for the year. 
Table 2

Fund returns by size and age

\begin{tabular}{|c|c|c|c|c|c|c|c|c|}
\hline Period & $\begin{array}{l}\text { Age } \\
\text { group }\end{array}$ & $\begin{array}{l}\text { Size 1 } \\
\text { (large) }\end{array}$ & Size 2 & Size 3 & Size 4 & $\begin{array}{l}\text { Size } 5 \\
\text { (Small) }\end{array}$ & S5-S1 & $\begin{array}{l}\text { Pr. } \\
\text { (S5-S1) }\end{array}$ \\
\hline \multicolumn{9}{|c|}{ Panel A: Retail Equity Funds } \\
\hline \multirow[t]{4}{*}{$1995-2005$} & $\mathrm{O}$ & 0.0096 & 0.0099 & 0.009 & 0.0114 & 0.0012 & $-0.0085^{*}$ & 0.02 \\
\hline & $\mathrm{Y}$ & 0.0103 & 0.0107 & 0.0092 & 0.0091 & 0.0093 & -0.0011 & 0.38 \\
\hline & $\mathrm{Y}-\mathrm{O}$ & 0.0007 & 0.0008 & 0.0001 & -0.0023 & $0.0081 *$ & & \\
\hline & $\operatorname{Pr}(\mathrm{Y}-\mathrm{O})$ & 0.42 & 0.41 & 0.49 & 0.27 & 0.02 & & \\
\hline \multirow[t]{4}{*}{ 1995-1999 } & $\mathrm{O}$ & 0.0104 & 0.0107 & 0.0100 & 0.0120 & -0.0045 & $-0.0150 *$ & 0.02 \\
\hline & $\mathrm{Y}$ & 0.0110 & 0.0122 & 0.0090 & 0.0090 & 0.0100 & -0.0010 & 0.43 \\
\hline & $\mathrm{Y}-\mathrm{O}$ & 0.0006 & 0.0015 & -0.001 & -0.0029 & $0.0146^{*}$ & & \\
\hline & $\operatorname{Pr}(\mathrm{Y}-\mathrm{O})$ & 0.46 & 0.4 & 0.43 & 0.31 & 0.02 & & \\
\hline \multirow[t]{4}{*}{$2000-2005$} & $\mathrm{O}$ & 0.0090 & 0.0092 & 0.0082 & 0.0109 & 0.0061 & -0.0028 & 0.24 \\
\hline & $\mathrm{Y}$ & 0.0097 & 0.0093 & 0.0094 & 0.0092 & 0.0086 & -0.0011 & 0.40 \\
\hline & $\mathrm{Y}-\mathrm{O}$ & 0.0008 & 0.0002 & 0.0011 & -0.0018 & 0.0025 & & \\
\hline & $\operatorname{Pr}(\mathrm{Y}-\mathrm{O})$ & 0.43 & 0.49 & 0.4 & 0.36 & 0.25 & & \\
\hline \multicolumn{9}{|c|}{ Panel B: Wholesale NTP Funds } \\
\hline \multirow[t]{4}{*}{ 1995-2005 } & $\mathrm{O}$ & 0.0107 & 0.0099 & 0.0098 & 0.0081 & 0.0104 & -0.0003 & 0.46 \\
\hline & $\mathrm{Y}$ & 0.0115 & 0.0123 & 0.0107 & 0.0107 & 0.0114 & -0.0001 & 0.49 \\
\hline & $\mathrm{Y}-\mathrm{O}$ & 0.0008 & 0.0023 & 0.0008 & 0.0026 & 0.001 & & \\
\hline & $\operatorname{Pr}(\mathrm{Y}-\mathrm{O})$ & 0.41 & 0.25 & 0.41 & 0.24 & 0.37 & & \\
\hline \multirow[t]{4}{*}{ 1995-1999 } & $\mathrm{O}$ & 0.0117 & 0.0103 & 0.0094 & 0.0073 & 0.0106 & -0.0011 & 0.42 \\
\hline & $\mathrm{Y}$ & 0.0132 & 0.0134 & 0.0110 & 0.0120 & 0.0135 & 0.0003 & 0.48 \\
\hline & $\mathrm{Y}-\mathrm{O}$ & 0.0016 & 0.0031 & 0.0017 & 0.0047 & 0.0029 & & \\
\hline & $\operatorname{Pr}(\mathrm{Y}-\mathrm{O})$ & 0.39 & 0.29 & 0.39 & 0.22 & 0.29 & & \\
\hline \multirow[t]{4}{*}{$2000-2005$} & $\mathrm{O}$ & 0.0099 & 0.0096 & 0.0102 & 0.0087 & 0.0102 & 0.0003 & 0.47 \\
\hline & $\mathrm{Y}$ & 0.0100 & 0.0113 & 0.0103 & 0.0095 & 0.0096 & -0.0004 & 0.46 \\
\hline & $\mathrm{Y}-\mathrm{O}$ & 0.0001 & 0.0017 & 0.0001 & 0.0008 & -0.0006 & & \\
\hline & $\operatorname{Pr}(\mathrm{Y}-\mathrm{O})$ & 0.49 & 0.35 & 0.49 & 0.43 & 0.43 & & \\
\hline \multicolumn{9}{|c|}{ Panel C: Wholesale PST Fund } \\
\hline \multirow[t]{4}{*}{$1995-2005$} & $\mathrm{O}$ & 0.0094 & 0.0098 & 0.0094 & 0.0100 & 0.0065 & -0.0029 & 0.18 \\
\hline & $\mathrm{Y}$ & 0.0108 & 0.0102 & 0.0109 & 0.0094 & 0.0084 & -0.0025 & 0.25 \\
\hline & $\mathrm{Y}-\mathrm{O}$ & 0.0014 & 0.0004 & 0.0015 & -0.0006 & 0.0019 & & \\
\hline & $\operatorname{Pr}(\mathrm{Y}-\mathrm{O})$ & 0.35 & 0.45 & 0.33 & 0.42 & 0.26 & & \\
\hline \multirow[t]{4}{*}{ 1995-1999 } & $\mathrm{O}$ & 0.0107 & 0.0099 & 0.0101 & 0.0110 & 0.0104 & -0.0003 & 0.47 \\
\hline & $\mathrm{Y}$ & 0.0113 & 0.0097 & 0.0127 & 0.0106 & 0.0094 & -0.0020 & 0.36 \\
\hline & $\mathrm{Y}-\mathrm{O}$ & 0.0006 & -0.0002 & 0.0026 & -0.0004 & -0.0010 & & \\
\hline & $\operatorname{Pr}(\mathrm{Y}-\mathrm{O})$ & 0.46 & 0.49 & 0.34 & 0.47 & 0.41 & & \\
\hline \multirow[t]{4}{*}{ 2000-2005 } & $\mathrm{O}$ & 0.0083 & 0.0097 & 0.0089 & 0.0092 & 0.0031 & $-0.0051+$ & 0.08 \\
\hline & $\mathrm{Y}$ & 0.0101 & 0.0107 & 0.0094 & 0.0084 & 0.0075 & -0.0025 & 0.31 \\
\hline & $\mathrm{Y}-\mathrm{O}$ & 0.0018 & 0.0009 & 0.0005 & -0.0008 & 0.0044 & & \\
\hline & $\operatorname{Pr}(\mathrm{Y}-\mathrm{O})$ & 0.35 & 0.4 & 0.45 & 0.42 & 0.12 & & \\
\hline
\end{tabular}

Note: The data used in analysis is drawn from all Morningstar wholesale NTP, PST and Retail Australian equity available for the period, December 1994 to September 2005. The fund return is calculated for each size/age portfolio for each month in the sample period. The portfolios are rebalanced each month. The funds are sorted by Size 1 (largest funds) though to Size 5 (smallest funds) and by age into either Old (O) or Young (Y) classifications. Pr. is the Probability from t-tests comparing the mean fund return for the largest (oldest) and the smallest (youngest) portfolio and these are reported for the full period and for each of the sub periods. * (+) statistically significant at the 5\% (10\%) level of significance. 
Table 3

Risk adjusted fund returns by size and age

\begin{tabular}{|c|c|c|c|c|c|c|c|c|}
\hline Period & $\begin{array}{l}\text { Age } \\
\text { group }\end{array}$ & $\begin{array}{l}\text { Size } 1 \\
\text { (large) }\end{array}$ & Size 2 & Size 3 & Size 4 & $\begin{array}{l}\text { Size } 5 \\
(\text { Small) }\end{array}$ & S5-S1 & $\begin{array}{l}\text { Pr. } \\
\text { (S5-S }\end{array}$ \\
\hline \multicolumn{9}{|l|}{ Panel A: } \\
\hline \multicolumn{9}{|l|}{ Retail Equity Funds } \\
\hline \multirow[t]{6}{*}{$1995-2005$} & $\mathrm{O}$ & 0.0007 & 0.0007 & -0.0004 & 0.0021 & $-0.0069 *$ & $-0.0076 *$ & 0.01 \\
\hline & & -0.35 & -0.50 & -0.66 & -0.22 & -0.02 & & \\
\hline & $\mathrm{Y}$ & 0.0012 & $0.0019 *$ & 0.0000 & 0.0004 & 0.0007 & -0.0006 & 0.49 \\
\hline & & -0.15 & -0.01 & -0.99 & -0.61 & -0.47 & & \\
\hline & $\mathrm{Y}-\mathrm{O}$ & 0.0006 & 0.0011 & 0.0004 & -0.0017 & $0.0076 *$ & & \\
\hline & $\operatorname{Pr}(\mathrm{Y}-\mathrm{O})$ & 0.35 & 0.15 & 0.63 & 0.30 & 0.01 & & \\
\hline \multirow[t]{6}{*}{ 1995-1999 } & $\mathrm{O}$ & 0.0000 & -0.0007 & -0.0009 & 0.0008 & $-0.0142 *$ & $-0.0142 *$ & 0.01 \\
\hline & & -0.99 & -0.67 & -0.54 & -0.70 & -0.01 & & \\
\hline & $\mathrm{Y}$ & 0.0005 & 0.0016 & $-0.0020+$ & -0.0015 & -0.0005 & -0.001 & 0.37 \\
\hline & & -0.73 & -0.16 & -0.06 & -0.20 & -0.7 & & \\
\hline & $\mathrm{Y}-\mathrm{O}$ & 0.0005 & $0.0023^{*}$ & -0.0011 & -0.0024 & $0.0137 *$ & & \\
\hline & $\operatorname{Pr}(\mathrm{Y}-\mathrm{O})$ & 0.54 & 0.05 & 0.48 & 0.28 & 0.02 & & \\
\hline \multirow[t]{6}{*}{$2000-2005$} & $\mathrm{O}$ & 0.0012 & 0.0019 & 0.0003 & 0.0008 & 0.0000 & -0.0013 & 0.59 \\
\hline & & -0.14 & -0.17 & -0.84 & -0.76 & -0.99 & & \\
\hline & $\mathrm{Y}$ & $0.0028 *$ & 0.0012 & 0.0013 & 0.0015 & 0.0013 & -0.0016 & 0.17 \\
\hline & & -0.01 & -0.18 & -0.15 & -0.17 & -0.27 & & \\
\hline & $\mathrm{Y}-\mathrm{O}$ & $0.0016+$ & -0.0007 & 0.0010 & 0.0007 & 0.0013 & & \\
\hline & $\operatorname{Pr}(\mathrm{Y}-\mathrm{O})$ & 0.07 & 0.51 & 0.33 & 0.79 & 0.59 & & \\
\hline
\end{tabular}

Panel B:

Wholesale NTP Funds 1995-2005

1995-1999

2000-2005

$\begin{array}{llllllll}\mathrm{O} & 0.0016^{*} & 0.0010 & 0.0010 & -0.0016+ & 0.0021^{*} & 0.0004 & 0.56 \\ \mathrm{Y} & -0.03 & -0.20 & -0.32 & -0.09 & -0.01 & & \\ & 0.0023^{*} & 0.0031^{*} & 0.0012 & 0.0016+ & 0.0027^{*} & 0.0005 & 0.62 \\ \mathrm{Y}-\mathrm{O} & -0.01 & 0.00 & -0.17 & -0.07 & -0.01 & & \\ \mathrm{Pr}(\mathrm{Y}-\mathrm{O}) & 0.0006 & 0.0021^{*} & 0.0002 & 0.0032^{*} & 0.0006 & & \\ \mathrm{O} & 0.31 & 0.01 & 0.86 & 0.00 & 0.52 & & \\ & 0.0007 & 0.0000 & -0.0009 & -0.0043^{*} & 0.0007 & 0 & 1 \\ \mathrm{Y} & -0.54 & -0.98 & -0.60 & 0.00 & -0.59 & & \\ & 0.0020 & 0.0025 & -0.0005 & 0.0008 & 0.003 & 0.001 & 0.6 \\ \mathrm{Y}-\mathrm{O} & -0.12 & -0.10 & -0.77 & -0.59 & -0.11 & & \\ \operatorname{Pr}(\mathrm{Y}-\mathrm{O}) & 0.0013 & 0.0025+ & 0.0005 & 0.0051^{*} & 0.0023 & & \\ \mathrm{O} & 0.22 & 0.09 & 0.81 & 0.00 & 0.22 & & \\ & 0.0021 * & 0.0014 & 0.0024^{*} & 0.0005 & 0.0031^{*} & 0.001 & 0.29 \\ \mathrm{Y} & -0.04 & -0.14 & -0.04 & -0.60 & -0.01 & & \\ & 0.0021^{*} & 0.0038^{*} & 0.0026^{*} & 0.0020^{*} & 0.0024^{*} & 0.0004 & 0.63 \\ \mathrm{Y}-\mathrm{O} & -0.05 & 0.00 & 0.00 & -0.02 & -0.01 & & \\ \operatorname{Pr}(\mathrm{Y}-\mathrm{O}) & 0.0000 & 0.0025^{*} & 0.0001 & 0.0015+ & -0.0007 & & \end{array}$

Panel C:

Wholesale PST Funds 1995-2005

$\begin{array}{lcclllll}\mathrm{O} & 0.0004 & 0.0008 & -0.0004 & 0.0019 * & -0.0013 & -0.0016 & 0.19 \\ & -0.59 & -0.42 & -0.70 & -0.05 & -0.26 & & \\ \mathrm{Y} & 0.0003 & 0.0013 & 0.0023^{*} & 0.0011 & 0.0000 & -0.0004 & 0.84 \\ & -0.82 & -0.31 & -0.04 & -0.28 & -0.97 & & \\ \mathrm{Y}-\mathrm{O} & 0.0000 & 0.0005 & 0.0027^{*} & -0.0008 & 0.0012 & & \\ \mathrm{Pr}(\mathrm{Y}-\mathrm{O}) & 0.99 & 0.67 & 0.05 & 0.42 & 0.36 & & \end{array}$




\begin{tabular}{|c|c|c|c|c|c|c|c|c|}
\hline \multirow[t]{6}{*}{ 1995-1999 } & \multirow[t]{2}{*}{$\mathrm{O}$} & -0.0002 & -0.001 & -0.0023 & 0.001 & 0.0011 & \multirow[t]{2}{*}{0.0013} & \multirow[t]{2}{*}{0.48} \\
\hline & & -0.73 & -0.50 & -0.23 & -0.50 & -0.49 & & \\
\hline & \multirow[t]{2}{*}{$\mathrm{Y}$} & 0.0005 & -0.0015 & 0.0021 & 0.0008 & -0.0002 & \multirow[t]{4}{*}{-0.0007} & \multirow[t]{4}{*}{0.74} \\
\hline & & -0.78 & -0.51 & -0.25 & -0.53 & -0.90 & & \\
\hline & $\mathrm{Y}-\mathrm{O}$ & 0.0007 & -0.0005 & $0.0045+$ & -0.0002 & -0.0014 & & \\
\hline & $\operatorname{Pr}(\mathrm{Y}-\mathrm{O})$ & 0.62 & 0.82 & 0.06 & 0.90 & 0.48 & & \\
\hline \multirow[t]{6}{*}{ 2000-2005 } & $\mathrm{O}$ & 0.0006 & $0.0025+$ & $0.0017+$ & $0.0024+$ & $-0.0031 *$ & \multirow[t]{2}{*}{$-0.0037 *$} & \multirow[t]{2}{*}{0.03} \\
\hline & & -0.54 & -0.06 & -0.09 & -0.07 & -0.05 & & \\
\hline & \multirow[t]{2}{*}{$\mathrm{Y}$} & 0.0009 & $0.0046 *$ & 0.002 & 0.0001 & -0.0001 & \multirow[t]{4}{*}{-0.001} & \multirow[t]{4}{*}{0.67} \\
\hline & & -0.65 & 0.00 & -0.16 & -0.95 & -0.92 & & \\
\hline & Y-O & 0.0002 & $0.0022 *$ & 0.0003 & $-0.0023+$ & $0.0030 *$ & & \\
\hline & $\operatorname{Pr}(\mathrm{Y}-\mathrm{O})$ & 0.91 & 0.03 & 0.85 & 0.07 & 0.05 & & \\
\hline
\end{tabular}

The data used in analysis are drawn from all Morningstar wholesale NTP, PST and Retail Australian equity funds that exist during the sample period from December 1994 to September 2005. The fund return is calculated for each size/age portfolio for each month in the sample period. The funds are sorted by Size 1 (largest funds) though to Size 5 (smallest funds) and by age into Old (O) or Young (Y) classifications. The return is then calculated for the month for each of the portfolios and this procedure is repeated each month through to the end of the sample period. Excess returns are estimated using the four factor asset pricing model of Elton Gruber and Blake (1996) and Gruber (1996) and to facilitate tests for differences in risk adjusted size/age portfolio excess returns estimation is carried out over the system of 10 equations using seemingly unrelated regressions (SURE). The estimated risk adjusted size/age portfolio return is reported for each of the size/age portfolios and the t-test probability for this coefficient is reported in parentheses below the estimate. The separate column and row headed "Prob." refers to chi-square test probabilities for the test of the restriction that the two risk-adjusted returns are equal. *(+) statistically significant at the 5\% (10\%) level of significance. 
Table 4

Impact of past returns on fund cash flows: A random effects panel analysis

\begin{tabular}{|c|c|c|c|c|c|c|}
\hline Variables & $\begin{array}{c}1995 \\
\text { to } 2005\end{array}$ & $\begin{array}{c}1995 \\
\text { to } 2005\end{array}$ & $\begin{array}{c}1995 \\
\text { to } 1999\end{array}$ & $\begin{array}{c}1995 \\
\text { to } 1999\end{array}$ & $\begin{array}{c}2000 \\
\text { to } 2005\end{array}$ & $\begin{array}{c}2000 \\
\text { to } 2005\end{array}$ \\
\hline \multicolumn{7}{|l|}{ Panel A: Retail Equity Funds } \\
\hline \multirow[t]{2}{*}{ Lag excess return } & $0.5800 *$ & $0.4661 *$ & 0.4826 & $0.5048 *$ & $0.5036^{*}$ & $0.4626^{*}$ \\
\hline & 0.00 & 0.00 & -0.29 & -0.01 & -0.01 & -0.01 \\
\hline \multirow[t]{2}{*}{ Fund age } & $-0.0728 *$ & $-0.0631 *$ & $-0.0470 *$ & $-0.0372 *$ & $-0.0706^{*}$ & $-0.0593^{*}$ \\
\hline & 0.00 & 0.00 & 0.00 & 0.00 & 0.00 & 0.00 \\
\hline \multirow[t]{2}{*}{ Management expense ratio } & -0.0695 & & -0.032 & & -0.0674 & \\
\hline & -0.43 & & -0.85 & & -0.45 & \\
\hline \multirow[t]{2}{*}{ Lag volatility } & $0.8798+$ & $0.6782 *$ & $-1.6249+$ & $-0.6881+$ & $1.8436^{*}$ & $1.4672 *$ \\
\hline & -0.06 & -0.04 & -0.08 & -0.08 & 0.00 & 0.00 \\
\hline \multirow[t]{2}{*}{ Equity market conditions } & 0.0453 & 0.0106 & -0.0446 & 0.0365 & $0.1030 *$ & 0.0179 \\
\hline & -0.20 & -0.72 & -0.50 & -0.42 & -0.02 & -0.66 \\
\hline Fund family dummy variables & yes & yes & yes & yes & yes & Yes \\
\hline Sample size & 1604 & 2217 & 338 & 594 & 1266 & 1623 \\
\hline Rsquare & 0.26 & 0.23 & 0.30 & 0.34 & 0.29 & 0.24 \\
\hline \multicolumn{7}{|l|}{ Panel B: Wholesale NTP Funds } \\
\hline \multirow[t]{2}{*}{ Lag excess return } & $1.7909 *$ & $1.2266^{*}$ & $1.6252+$ & $0.9377+$ & $1.8978^{*}$ & $1.3056^{*}$ \\
\hline & 0.00 & 0.00 & -0.06 & -0.07 & 0.00 & 0.00 \\
\hline \multirow[t]{2}{*}{ Fund age } & $-0.0814^{*}$ & $-0.0908 *$ & $-0.0724 *$ & $-0.0902 *$ & $-0.0626 *$ & $-0.0682 *$ \\
\hline & 0.00 & 0.00 & -0.02 & 0.00 & 0.00 & 0.00 \\
\hline \multirow[t]{2}{*}{ Management expense ratio } & -0.0657 & & -0.2081 & & -0.0125 & \\
\hline & -0.80 & & -0.76 & & -0.96 & \\
\hline \multirow[t]{2}{*}{ Lag volatility } & 0.9283 & 1.1244 & -1.7583 & -0.1876 & 1.835 & 1.2698 \\
\hline & -0.42 & -0.13 & -0.31 & -0.85 & -0.16 & -0.14 \\
\hline \multirow[t]{2}{*}{ Equity market conditions } & $-0.1392+$ & -0.0389 & 0.1551 & 0.0678 & $-0.2398 *$ & $-0.1366+$ \\
\hline & -0.07 & -0.49 & -0.25 & -0.46 & -0.01 & -0.06 \\
\hline Fund family dummy variables & yes & yes & yes & yes & yes & yes \\
\hline Sample size & 1056 & 1596 & 176 & 304 & 880 & 1292 \\
\hline Rsquare & 0.18 & 0.16 & 0.24 & 0.32 & 0.22 & 0.19 \\
\hline \multicolumn{7}{|l|}{ Panel C: Wholesale PST Funds } \\
\hline \multirow[t]{2}{*}{ Lag excess return } & $1.4094 *$ & 0.7504 & 4.6346 & -1.3829 & $1.0919+$ & 0.8833 \\
\hline & -0.03 & -0.23 & -0.13 & -0.48 & -0.09 & -0.20 \\
\hline \multirow[t]{2}{*}{ Fund age } & $-0.1333 *$ & $-0.1084 *$ & $-0.2024 *$ & -0.068 & $-0.0920 *$ & $-0.0910^{*}$ \\
\hline & 0.00 & 0.00 & -0.04 & -0.35 & 0.00 & 0.00 \\
\hline \multirow[t]{2}{*}{ Management expense ratio } & $-1.8155^{*}$ & & -1.704 & & -1.2716 & \\
\hline & -0.02 & & -0.37 & & -0.18 & \\
\hline \multirow[t]{2}{*}{ Lag volatility } & 1.5019 & 1.4048 & 4.261 & $7.2270 *$ & 1.777 & -0.2875 \\
\hline & -0.29 & -0.25 & -0.18 & -0.01 & -0.28 & -0.85 \\
\hline \multirow[t]{2}{*}{ Equity market conditions } & 0.0761 & 0.1292 & 0.0348 & 0.12 & -0.0317 & -0.0198 \\
\hline & -0.45 & -0.16 & -0.85 & -0.4 & -0.8 & -0.87 \\
\hline Fund family dummy variables & yes & yes & yes & yes & yes & yes \\
\hline Sample size & 212 & 434 & 59 & 109 & 153 & 325 \\
\hline $\mathrm{R}$ square & 0.31 & 0.36 & 0.38 & 0.35 & 0.25 & 0.41 \\
\hline
\end{tabular}

The data used in this analysis are drawn from all Morningstar wholesale NTP, PST and Retail

Australian equity funds that exist during the sample period from December 1994 to September 2005.

Fund cash flow is the dependent variable and this is the continuously compounded growth rate in net assets under management calculated for each fund for each available 12 month period. Lag excess returns is the continuously compounding return earned by the fund in excess of the Australian All 
Ordinaries share price accumulation index for the previous year. Fund age is the number of whole years since inception of the fund. Management expense ratio is the expense ratio provided by Morningstar as at September 2005. Lag volatility is the standard deviation in excess returns for the fund in the previous year. Equity market conditions is a dummy variable with value of one when the share market return for the year exceeds the average share market return over the period from 1995 to 2005 and zero otherwise. Fund family dummy variables consist of the set of dummy variables included in the model to capture the incremental asset flow attributable to fund families with 106 family dummy variables for the Retail equity funds, 78 for the NTP funds and 29 for the PST funds. The $t$-statistic probabilities are reported in parentheses below the parameter estimates. $*(+)$ statistically significant at the $5 \%(10 \%)$ level of significance. 